\title{
Use of milk fatty acids to estimate plasma nonesterified fatty acid concentrations as an indicator of animal energy balance
}

\author{
J. R. R. Dórea, E. A. French, and L. E. Armentano ${ }^{1}$ \\ Department of Dairy Science, University of Wisconsin, Madison 53706
}

\begin{abstract}
Negative energy balance is an important part of the lactation cycle, and measuring the current energy balance of a cow is useful in both applied and research settings. The objectives of this study were (1) to determine if milk fatty acid (FA) proportions were consistently related to plasma nonesterified fatty acids (NEFA); (2) to determine if an individual cow with a measured milk FA profile is above or below a NEFA concentration, (3) to test the universality of the models developed within the University of Wisconsin and US Dairy Forage Research Center cows. Blood samples were collected on the same day as milk sampling from 105 Holstein cows from 3 studies. Plasma NEFA was quantified and a threshold of $600 \mu \mathrm{Eq} / \mathrm{L}$ was applied to classify animals above this concentration as having high NEFA $\left(\mathrm{NEFA}_{\text {high }}\right)$. Thirty milk FA proportions and 4 milk FA ratios were screened to evaluate their capacity to classify cows with $\mathrm{NEFA}_{\text {high }}$ according to determined milk FA threshold. In addition, 6 linear regression models were created using individual milk FA proportions and ratios. To evaluate the universality of the linear relationship between milk FA and plasma NEFA found in the internal data set, 90 treatment means from 21 papers published in the literature were compiled to test the model predictions. From the 30 screened milk FA, the odd short-chain fatty acids (C7:0, C9:0, C11:0, and C13:0) had sensitivity slightly greater than the other short-chain fatty acids $(83.3,94.8,80.0$, and $85.9 \%$, respectively). The sensitivities for milk FA C6:0, C8:0, C10:0, and C12:0 were 78.8, 85.3, 80.1, and $83.9 \%$, respectively. The threshold values to detect NE$\mathrm{FA}_{\text {high }}$ cows for the last group of milk FA were $\leq 2.0$, $\leq 0.94, \leq 1.4$, and $\leq 1.8 \mathrm{~g} / 100 \mathrm{~g}$ of FA, respectively. The milk FA C14:0 and C15:0 had sensitivities of 88.7 and $85.0 \%$ and a threshold of $\leq 6.8$ and $\leq 0.53 \mathrm{~g} / 100 \mathrm{~g}$ of FA, respectively. The linear regressions using the milk
\end{abstract}

Received December 15, 2016.

Accepted March 29, 2017.

${ }^{1}$ Corresponding author: learment@wisc.edu
FA ratios $\mathrm{C} 18: 1$ to $\mathrm{C} 15: 0$ and $\mathrm{C} 17: 0$ to $\mathrm{C} 15: 0$ presented lower root mean square error $(\mathrm{RMSE}=191$ and 179 $\mu \mathrm{Eq} / \mathrm{L}$, respectively) in comparison with individual milk FA proportions $(\mathrm{RMSE}=194 \mu \mathrm{Eq} / \mathrm{L}), \mathrm{C} 18: 1$ to even short-medium-chain fatty acid (C4:0-C12:0) ratio $(\mathrm{RMSE}=220 \mu \mathrm{Eq} / \mathrm{L}$ ), and C18:1 to C14:0 (RMSE $=199 \mu \mathrm{Eq} / \mathrm{L})$. Models using milk FA ratios C18:1 to C15:0 and C17:0 to C15:0 had a better fit with the external data set in comparison with the other models. Plasma NEFA can be predicted by linear regression models using milk FA ratios.

Key words: energy balance, linear regression, milk fatty acid, threshold

\section{INTRODUCTION}

Negative energy balance (NEB) can lead to a variety of early lactation metabolic disorders, reduced fertility, and ultimately decreased milk production (Collard et al., 2000). One indicator of NEB related to adipose mobilization is elevated plasma nonesterified fatty acid (NEFA) concentrations (Grummer, 1993). Increased plasma NEFA concentration is correlated with greater prevalence of fatty liver, mastitis, dystocia, retained placenta, and displaced abomasum (van Knegsel et al., 2005). In addition to use for monitoring successful adaptation during early lactation, a sudden elevation in plasma NEFA could be an early indicator of reduced feed intake, which may be otherwise unnoticed for individual cows in a group management setting.

Milk fatty acids (FA) are related to stage of lactation in a manner suggesting they relate to the energy balance of dairy cows. Craninx et al. (2008) reported that as animals increased in DIM, the ratio of milk cis-9 C18:1 to C14:0 and C17:0 to C15:0 decreased. This relationship suggests a negative correlation between these milk FA ratios and improved energy balance that occurs as lactation proceeds. However, neither plasma NEFA concentrations nor actual energy balance were reported.

Recent studies have proposed the use of milk cis-9 C18:1 proportion of total milk FA as a biomarker to diagnose plasma NEFA above a specific threshold (Jor- 
jong et al., 2014, 2015; Mann et al., 2016) and the use of $\mathrm{C} 18: 1$ to $\mathrm{C} 15: 0$ ratio as a potential tool to diagnose hyperketonemia incidence. However, in those studies the thresholds and the relationship between plasma NEFA and milk FA were defined based on single studies. The milk FA were analyzed in samples collected from a single time point: 10 DIM (Mann et al., 2016), or after the second week postpartum (Jorjong et al., 2014). The use of single studies with the cohorts on the same diet and management practices likely limits the variability of milk fat composition (Mann et al., 2016) as well as the capacity to generalize the information across herds. Thus, our objectives were (1) to determine if milk FA proportions were consistently related to plasma NEFA across multiple studies and milk sample time points, (2) to determine a milk FA threshold to identify cows with elevated plasma NEFA, and (3) to test the universality of linear models developed within the University of Wisconsin and US Dairy Forage Research Center (USDFRC) in an external data set from other published experiments.

\section{MATERIALS AND METHODS}

This study was divided into 3 parts. First, we screened 30 milk FA (\% total milk FA; C4:0, C5:0, C6:0, C7:0, C8:0, C9:0, C10:0, C11:0, C12:0, C13:0, C14:0, iso-C14:0, cis-9 C14:1, C15:0, iso-C15:0, anteisoC15:0, C16:0, iso-C16:0, cis-9 C16:1, C17:0, iso-C17:0, anteiso-C17:0, cis-9 C17:1, C18:0, total C18:1, cis-9 cis12 C18:2, cis-9 trans-11 C18:2, trans-10 cis-12 C18:2, cis-9 cis-12 cis-15 C18:3, and cis-6 cis-9 cis-12 C18:3) and 4 milk FA ratios [C17:0 to C15:0, C18:1 to C15:0, C18:1 to C14:0, and C18:1 to even short-medium-chain fatty acids (eSMCFA)] from 3 short-term experiments (French et al., 2012; Lobos Sandoval, 2009; R. Grummer, emeritus professor, University of Wisconsin, Madison, unpublished data) to evaluate the capacity of those FA proportions to classify cows with elevated plasma NEFA concentration (NEFA $\geq 600 \mu \mathrm{Eq} / \mathrm{L}$ ) according to a determined milk FA threshold. The eSMCFA were considered as the sum of milk C4:0, C6:0, C8:0, C10:0, and C12:0. The milk FA thresholds were identified through receiver operating characteristic (ROC) curves when ROC area under the curve (AUC) was $\geq 0.80$. Second, we developed 6 linear regression models using the milk FA selected based on AUC $\geq 0.80$. Two models were developed based on individual milk FA proportions, and 4 models were developed using the milk FA ratios. Finally, we assessed if the linear models developed using individual animals from the University of Wisconsin and USDRFC studies fit an external data set from a wider population using treatment means from the literature.

\section{Experiment Descriptions}

The first of the 3 Wisconsin studies study was a $4 \times 4$ Latin square experiment ( 4 cows, $n=16$ observations, French et al., 2012). Four mid-lactation cows averaging 119 DIM were ruminally infused with acetate, propionate, isovalerate, or anteisovalerate while being fed the same TMR. Measurements were taken over $8 \mathrm{~d}$ total (four 2-d periods). The infusion of both 3-methylbuyrate (isovalerate) and 2-methylbutyrate (anteisovalerate) markedly decreased DMI in comparison with acetate and propionate, but only 3-methylbuyrate increased plasma NEFA and BHB. In this study (French et al., 2012), some treatments induced high plasma NEFA concentration because the cows used in that trial were mid-lactation animals, and normally those animals would not have high NEFA.

The second study (60 cows, $\mathrm{n}=173$ observations used, Lobos Sandoval, 2009) was a transition cow study in completely randomized block design, where cows were fed the same basal ration until 3 wk postpartum. The diet contained $(\mathrm{g} / \mathrm{kg}$ of $\mathrm{DM}): 300$ corn silage, 200 alfalfa silage, 218 rolled high-moisture shelled corn, 25 alfalfa hay, and 235 concentrate mixture, with supplemental vitamins and minerals. Milk and blood samples were collected weekly over the first 3 wk of lactation for milk FA and plasma NEFA analysis $(7,14$, and 21 d postpartum).

The third study used in the data set was another transition cow study where animals were used in a completely randomized block design (45 cows, $\mathrm{n}=15$ sampled observations; R. Grummer, emeritus professor, University of Wisconsin, Madison, unpublished data). The 2 different experimental diets fed were $(\mathrm{g} / \mathrm{kg}$ of DM): 240 corn silage, 240 alfalfa silage, and 520 of a concentrate mixture containing supplemental vitamins and minerals. The difference between the 2 diets was the addition of $20 \mathrm{~g} / \mathrm{kg}$ of DM calcium salts with different FA profiles. Diet A contained the majority of total diet FA as $\mathrm{C} 16: 0$ (45.6\%) and cis-C18:1 (36.5\%). Diet $\mathrm{B}$ contained the majority of total diet FA as cis-C18:1 (18.8\%) and trans-C18:1 (35.7\%). Milk FA and plasma NEFA concentrations were determined over the first 2 wk of lactation (2, 6, and $12 \mathrm{~d}$ postpartum).

In all 3 studies, milk was composited by cow by day based on milk volume produced at each milking. The composited milk samples were centrifuged for collection of fat cake for FA isolation by hexane-isopropanol extraction according to Hara and Radin (1978). Isolated milk fat was methylated and prepared for GLC analysis of individual known and unknown milk FA from C4:0 to C24:1 (Chouinard et al., 1999). Milk fat samples were analyzed on a PerkinElmer Clarus 500 (Norwalk, CT) using the column and temperature program described 
Table 1. Descriptive statistics for variables used in equation development $(\mathrm{n}=204)$

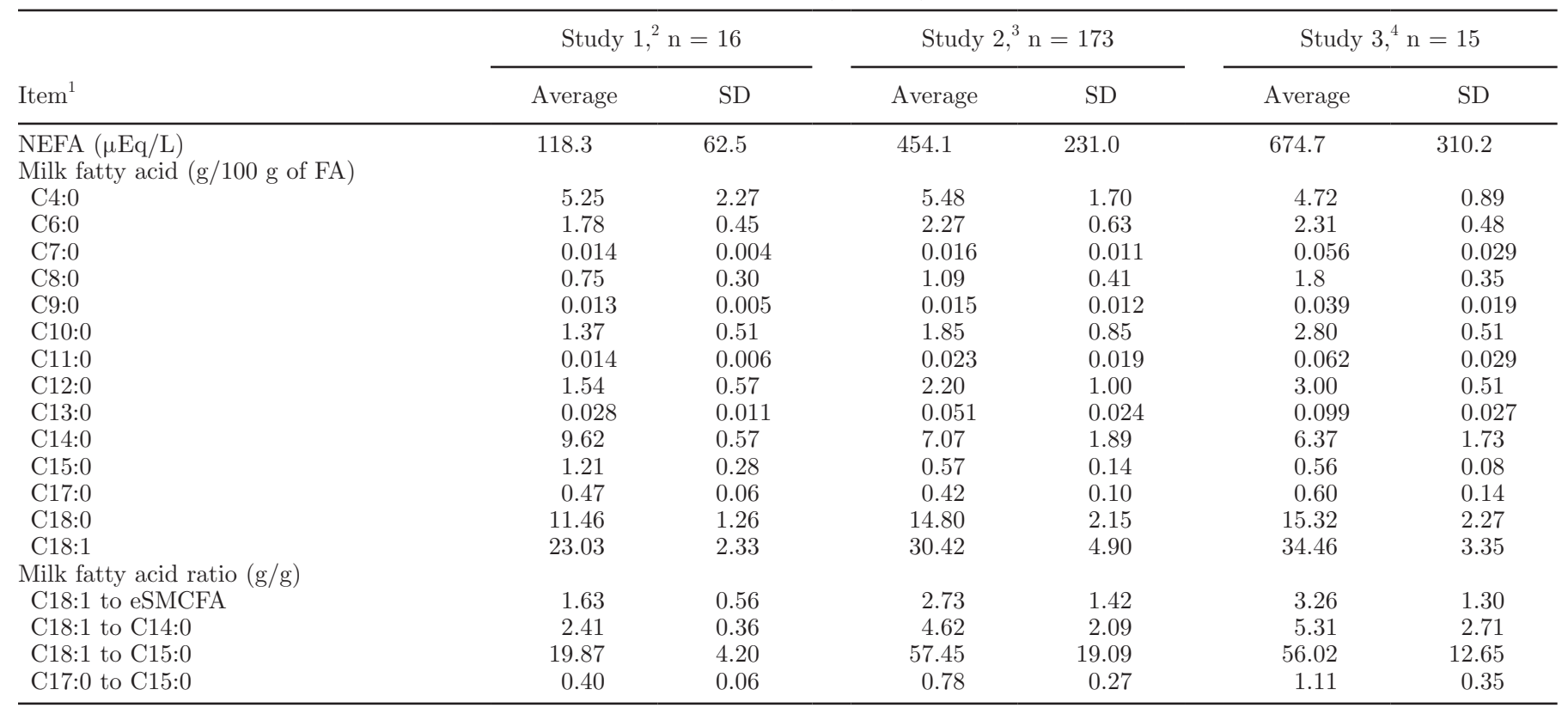

${ }^{1} \mathrm{NEFA}=$ nonesterified fatty acids; eSMCFA $=$ even short-medium-chain fatty acids (sum of C4:0, C6:0, C8:0, C10:0, and C12:0).

${ }^{2}$ Study $1=$ French et al. (2012), milk and blood samples from cows averaging 119 DIM.

${ }^{3}$ Study $2=$ Lobos Sandoval (2009), milk and blood samples from cows at 7, 14, and 21 DIM.

${ }^{4}$ Study $3=$ R. Grummer (emeritus professor, University of Wisconsin, Madison, personal communication), milk and blood samples from cows at 2,6 , and 12 DIM.

in French et al. (2012). Plasma NEFA was determined using an HR Series NEFA Number 2 kit (Wako Pure Chemical Industries Ltd., Richmond, VA; Novak, 1965).

Descriptive statistics for variables included in the analysis from the 3 studies are presented in Table 1 .

\section{Milk Fatty Acid Thresholds}

To determine the milk FA threshold values that would be used to identify individual cows with elevated plasma NEFA concentration $(\geq 600 \mu \mathrm{Eq} / \mathrm{L})$, a univariate logistic regression was performed with binary dependent variables $\mathrm{NEFA}_{\text {high }}(\geq 600 \mu \mathrm{Eq} / \mathrm{L})$ and NE$\mathrm{FA}_{\text {low }}(\leq 600 \mu \mathrm{Eq} / \mathrm{L})$, where $\mathrm{NEFA}_{\text {high }}$ was considered as test positive. All individual milk FA proportions and ratios were screened using the statistical software package JMP (v. 12.0, SAS Institute Inc., Cary, NC) for AUC of the ROC curve $\geq 0.80$. An AUC of 0.70 to 0.80 would be considered reasonable, whereas 0.80 to 0.90 AUC is considered good, and an AUC greater than 0.90 is excellent (Dohoo et al., 2003). The optimal milk FA thresholds were determined based on concentrations that maximized sensitivity and specificity as previously described by Ospina et al. (2010). Accuracy, sensitivity, specificity, and $95 \%$ confidence intervals were calculated for classification of animals as $\mathrm{NEFA}_{\text {high }} / \mathrm{NEFA}_{\text {low }}$ according to the respective threshold values using the IVD Performance Add-In package of JMP. Only milk FA that presented AUC $\geq 0.80$ had those parameters calculated. The plasma NEFA concentration of 600 $\mu \mathrm{Eq} / \mathrm{L}$ was chosen as the cut point based on the Ospina et al. (2010) study. Those authors reported that animals with plasma NEFA above $600 \mu \mathrm{Eq} / \mathrm{L}$ would have a greater risk of developing metabolic disorders.

\section{Linear Regression Models}

Two of the 6 developed models were a multiple linear regression built from individual milk FA proportions, and 4 were simple linear regressions built from milk FA ratios. As criteria to include the milk FA proportion in the multiple linear regressions (models 1 and 2), the potentially predictive milk FA were first screened by univariate logistic regression analysis to calculate a respective $P$-value (chi-squared test of $P \leq 0.15$ ) and an AUC $(\geq 0.80)$ of the ROC curve. Subsequently, these milk FA were submitted to a forward stepwise selection ( $P$-value $\leq 0.15$ as selection criterion), and finally evaluated for multicollinearity by calculating the variance inflation factor (VIF) for each predictive milk FA in PROC REG of SAS (version 8, SAS Institute Inc.). When VIF was $\geq 10$, multicollinearity was suspected 
the milk FA was removed and model was rebuilt until the VIF for all variables was $<10$.

For the second model (model 2), the milk FA of smaller proportions (C9:0 and C13:0) were excluded due to few reports of these milk FA in the external data set (published papers in the literature). This fact eliminated the possibility of testing model 1 in the external data set, and model 2 became the model with individual milk FA proportions to be tested. The last 4 models consisted of the following milk FA ratios: model 3: C18:1 to eSMCFA, model 4: C18:1 to C14:0, model 5: C18:1 to C15:0, and model 6: C17:0 to C15:0.

The PROC MIXED procedure of SAS was used to evaluate plasma NEFA and milk FA data combined from all 3 studies ( $\mathrm{n}=204$ observations from 105 cows). The concentration of plasma NEFA was regressed onto individual milk FA proportions and ratios. The models used to develop the equations included the fixed effect of milk FA (ratios or proportions of individual milk FA) and the random effect of diet within study. The covariance structure used for each model was chosen based on the lowest Akaike information criterion (AIC).

\section{External Data Set}

For model assessment, an external data set was compiled consisting of published papers from the literature. This data set was composed of treatment means for milk FA proportions and plasma NEFA concentration.

One review across 3 databases [Scielo (http:// scielo.org/php/index.php), Web of Science (https:// webofknowledge.com/), and Google Scholar (scholar. google.com)] and references in papers, was done to identify studies measuring milk FA and plasma NEFA concentrations. Combinations of the following search terms were used: NEFA, nonesterified fatty acids, milk fatty acids, NEB, transition period, dairy, and reproduction.

A data set consisting of 90 treatment means from 21 trials reported in 21 papers published between 1997 and 2015 (Griinari et al., 1997; Baumgard et al., 2000; Bernal-Santos et al., 2003; Mandebvu et al., 2003; Moore et al., 2004; Castañeda-Gutiérrez et al., 2005; Dann et al., 2005; Gonthier et al., 2005; Loor et al., 2005a,b; Kay et al., 2007; Odens et al., 2007; Penner and Oba, 2009; Petit and Cortês, 2010; Zachut et al., 2010; Halmemies-Beauchet-Filleau et al., 2011; Benchaar et al., 2014; Lerch et al., 2015; Petit, 2015; Pineda and Cardoso, 2015; Resende et al., 2015) was compiled for all milk FA proportions (g/100 g of FA) and plasma NEFA $(\mu \mathrm{Eq} / \mathrm{L})$.

The data set was analyzed using PROC MIXED of SAS. For the continuous independent variable (NEFA), the model included the fixed effects of milk FA (individual proportions or ratios) and the random effect of study. Prior to analysis in the external data set, the observed NEFA values were adjusted for a study as random effect, because the observations come from a multidimensional space (study effects), and they need to be collapsed from the multi-dimensional space into a 2-dimensional space (St. Pierre, 2001). It is important to adjust the observations for the lost dimensions or else the regression may be biased (St. Pierre, 2001). The data were not weighted by standard error of the mean because the high standard error of the mean for plasma NEFA concentration found in studies with transition cows are more related to physiological variation than experimental error. Thus, the data were weighted by the number of observation (n) used.

Adjusted plasma NEFA concentration $(\mathrm{n}=90$ treatment means, from 21 studies) was used as the observed mean. Milk FA ratios and the individual milk FA proportions, from the literature, were used to predict plasma NEFA concentration. The plasma NEFA concentration predicted by the developed linear models (University of Wisconsin and USDFRC, internal data set) were compared with the observed plasma NEFA (adjusted treatment means from the literature, external data set). Descriptive statistics for variables compiled from the published papers included in the analysis are presented in Table 2.

\section{Model Assessment}

The model evaluation was conducted as described by Tedeschi (2006). The precision of the developed equations was evaluated using the coefficient of determination between the predicted and observed values. The accuracy was calculated based on the concordance correlation coefficient (CCC), mean bias (MB), root of mean square error prediction (RMSEP).

Briefly, the CCC is the multiplication of the correlation coefficient between observed and predicted values by the bias correction $(\mathbf{C b})$, which indicates how far the regression line deviates from the slope of unity. The $\mathrm{CCC}$, correlation coefficient, and $\mathrm{Cb}$ statistics vary from 0 to 1 (Lin, 1989).

The RMSEP equation consists of the square root of mean square error prediction (MSEP), where MSEP is the sum of the squared difference between observed values and model-predicted values divided by the number of data points (n; Bibby and Toutenburg, 1977). The MSEP was decomposed into MB, slope bias, and random errors (Theil, 1961).

The decomposition of the MSEP into MB, slope bias, and random error components provides an indication 
Table 2. Descriptive statistics variables compiled from treatment means from studies published in the literature $(\mathrm{n}=90$ treatment means)

\begin{tabular}{lcccc}
\hline Item $^{1}$ & Average & SD & Minimum & Maximum \\
\hline NEFA $(\mu \mathrm{Eq} / \mathrm{L})$ & 330.6 & 258.3 & 74.0 & $1,569.0$ \\
Fatty acid $(\mathrm{g} / 100 \mathrm{~g}$ of $\mathrm{FA})$ & & & & \\
C4:0 & 3.82 & 1.48 & 1.51 & 10.2 \\
C6:0 & 1.92 & 0.47 & 0.88 & 3.14 \\
C8:0 & 1.01 & 0.30 & 0.43 & 4.72 \\
C10:0 & 2.20 & 0.77 & 0.73 & 5.95 \\
C12:0 & 2.54 & 0.93 & 0.93 & 13.57 \\
C14:0 & 9.01 & 2.26 & 4.28 & 1.83 \\
C15:0 & 0.91 & 0.33 & 0.43 & 19.90 \\
C17:0 & 0.61 & 0.14 & 0.32 & 37.73 \\
C18:0 & 12.72 & 3.14 & 3.49 & \\
C18:1 & 28.07 & 5.31 & 15.26 & 2.75 \\
Ratio (g/g) & & & & 7.69 \\
C18:1 to eSMCFA & 1.51 & 0.52 & 0.50 & 1.72 \\
C18:1 to C14:0 & 3.45 & 1.41 & 1.16 & 1.50 \\
C18:1 to C15:0 & 36.20 & 15.27 & 0.34 & \\
\hline
\end{tabular}

${ }^{1} \mathrm{NEFA}=$ nonesterified fatty acids; $\mathrm{eSMCFA}=$ even short-medium-chain fatty acids (sum of C4:0, C6:0, C8:0, C10:0, C12:0).

of the adequacy of the model for prediction. The MB represents the error in the central tendency (to assess whether the predicted values are over- or underpredicted), the slope bias represents errors due to regression, and the random component is the unexplained variance that cannot be accounted for by the linear regression (Tedeschi, 2006). Model evaluations were performed using the software Model Evaluation System (MES, College Station, TX; http://nutritionmodels.tamu.edu/ mes.html) as described by Tedeschi (2006).

\section{RESULTS AND DISCUSSION}

\section{Milk Fatty Acid Thresholds}

From the 30 milk FA screened by ROC curves, only 10 individual milk FA proportions had AUC $\geq 0.80$ (Table 3). Those milk FA were C6:0, C7:0, C8:0, C9:0, C10:0, C11:0, C12:0, C13:0, C14:0, and C15:0. Most of these milk FA are classified as de novo synthetized milk FA.

Table 3. Sensitivity, specificity, total accuracy, and thresholds for milk fatty acids (FA) screened through receiver operating characteristic curves and selected when area under the curve (AUC) was $\geq 0.80^{1}$

\begin{tabular}{|c|c|c|c|c|c|c|}
\hline Item & $\mathrm{AUC}^{2}$ & $\begin{array}{c}\text { Threshold } \\
\text { (g/100 g of FA) }\end{array}$ & $P$-value & $\begin{array}{c}\text { Sensitivity } \\
(\% ; 95 \% \text { CI })\end{array}$ & $\begin{array}{c}\text { Specificity } \\
(\% ; 95 \% \text { CI })\end{array}$ & $\begin{array}{c}\text { Accuracy } \\
(\% ; 95 \% \text { CI })\end{array}$ \\
\hline \multicolumn{7}{|c|}{ Milk FA (g/100 g of FA) } \\
\hline $\mathrm{C} 8: 0$ & 0.87 & $\overline{\leq} 0.94$ & $<0.01$ & $85.3(68.6-93.0)$ & $75.3(67.9-81.7)$ & $76.9(70.5-82.5)$ \\
\hline C9:0 & 0.84 & $\leq 0.011$ & $<0.01$ & $94.8(78.1-98.3)$ & $63.5(55.5-71.0)$ & $68.8(61.8-75.2)$ \\
\hline $\mathrm{C} 10: 0$ & 0.86 & $\overline{\leq} 1.40$ & $<0.01$ & $80.1(60.5-87.9)$ & $78.6(72.5-85.6)$ & $78.9(72.6-84.3)$ \\
\hline C13:0 & 0.90 & $\leq 0.036$ & $<0.01$ & $85.9(67.9-92.8)$ & $82.3(74.4-87.0)$ & $81.7(75.6-86.7)$ \\
\hline $\mathrm{C} 14: 0$ & 0.82 & $\overline{\leq} 6.80$ & $<0.01$ & $88.7(71.4-94.5)$ & $66.4(57.5-72.7)$ & $69.6(62.8-75.8)$ \\
\hline $\mathrm{C} 15: 0$ & 0.86 & $\leq 0.53$ & $<0.01$ & $85(74.3-96.0)$ & $70(58.8-73.8)$ & $71.0(64.3-77.2)$ \\
\hline \multicolumn{7}{|l|}{ Milk FA ratio $(\mathrm{g} / \mathrm{g})$} \\
\hline C18:1 to eSMCFA ${ }^{3}$ & 0.80 & $\geq 2.60$ & $<0.01$ & $80.9(65.8-91.4)$ & $70.5(60.7-75.5)$ & $71.0(64.3-74.4)$ \\
\hline C18:1 to C14:0 & 0.81 & $\geq 4.7$ & $<0.01$ & $80.9(65.8-91.4)$ & $70.2(59.4-74.4)$ & $70.0(63.3-76.3)$ \\
\hline C18:1 to C15:0 & 0.86 & $\geq \overline{6} 2.0$ & $<0.01$ & $80.9(65.8-91.4)$ & $80.3(71.2-84.4)$ & $79.0(72.6-84.3)$ \\
\hline
\end{tabular}

${ }^{1}$ Nonselected milk fatty acids and their respective AUC $(\leq 0.80)$ were $\mathrm{C} 4: 0=0.63$, C5:0 = 0.25, iso C14:0 = 0.57, cis-9 C14:1 = 0.72, iso C15:0 $=0.66$, anteiso $\mathrm{C} 15: 0=0.60, \mathrm{C} 16: 0=0.49$, iso $\mathrm{C} 16: 0=0.55$, cis-9 $\mathrm{C} 16: 1=0.67, \mathrm{C} 17: 0=0.66$, iso $\mathrm{C} 17: 0=0.54$, anteiso $\mathrm{C} 17: 0=0.49$, cis- 9 $\mathrm{C} 17: 1=0.68, \mathrm{C} 18: 0=0.72$, total $\mathrm{C} 18: 1=0.76$, cis-9 cis-12 C18:2 = 0.68, cis-9 trans-11 C18:2=0.55, trans-10 cis-12 C18:2=0.57, cis-9 cis-12 cis-15 $\mathrm{C} 18: 3=0.58$, cis- 6 cis-9 cis- $12 \mathrm{C} 18: 3=0.53$.

${ }^{2} \mathrm{AUC}=$ area under the curve for the positive outcome (nonesterified fatty acids $\geq 600 \mu \mathrm{Eq} / \mathrm{L}$ ).

${ }^{3} \mathrm{eSMCFA}=$ even short-medium-chain fatty acids (sum of C4:0, C6:0, C8:0, C10:0, and C12:0). 
The odd SCFA such as C7:0, C9:0, C11:0, and C13:0 had sensitivity [i.e., proportion of true positive (NE$\mathrm{FA}_{\text {high }}$ ) cows testing positive] slightly greater than the other SCFA. The sensitivities of milk C7:0, C9:0, C11:0, and $\mathrm{C} 13: 0$ were $83.3,94.8,80.0$, and $85.9 \%$, respectively. The sensitivities found for milk FA C6:0, C8:0, $\mathrm{C} 10: 0$, and $\mathrm{C} 12: 0$ were $78.8,85.3,80.1$, and $83.9 \%$, respectively. The threshold values to detect $\mathrm{NEFA}_{\text {high }}$ cows for the last group of milk FA were $\leq 2.0, \leq 0.94$, $\leq 1.4$, and $\leq 1.8 \mathrm{~g} / 100 \mathrm{~g}$ of FA, respectively.

According to Craninx et al. (2008), SMCFA (C4:0C14:0) are the result of de novo synthesis in the mammary gland, and the proportion of de novo milk FA decreases when plasma NEFA concentration increases. Thus, when the de novo milk FA are below the threshold the animal is classified as $\mathrm{NEFA}_{\text {high }}$, but when the proportion of these milk FA are above the threshold, the cow is classified as $\mathrm{NEFA}_{\text {low }}$ (lower than $600 \mu \mathrm{Eq} / \mathrm{L}$ ). Craninx et al. (2008) pointed out that SMCFA may suffer from a dilution effect when NEFA are high, but there may also be an inhibitory effect by the preformed FA (preformed, $>16$ carbons) of mammary synthesis of FA with 10 to 14 carbon atoms (Jenkins, 1999; Ferlay et al., 2006). Additionally, early lactation cows with low levels of feed intake may have the synthesis of de novo milk FA reduced due to a decrease in the rumen acetate to propionate ratio (Craninx et al., 2008).

During the transition period, the cow mobilizes body fat, which increases the proportion of preformed milk FA, such as C18:1 in the milk (Jorjong et al., 2015). Thus, lower SMCFA proportions in the milk during that period might be an indicator of body fat mobilization. Woolpert et al. (2016) collected bulk tank milk of 44 commercial farms in New York State and classified the farms based on the proportion of de novo synthesized FA (C4:0-C14:0) in the milk, being high de novo synthesis or low de novo synthesis. Those authors reported that farms with low de novo synthesis $(\mathrm{n}=$ 23) bulk tank milk presented animals with lower BCS, suggesting greater body fat mobilization for cows in those farms due to insufficient energy intake.

The milk C14:0 and C15:0 had sensitivities of 88.7 and $85.0 \%$, and total accuracy of 69.6 and $71.0 \%$ (Table 3). Based on the sensitivity values, both milk FA showed high potential to identify cows with plasma NEFA concentrations above $600 \mu \mathrm{Eq} / \mathrm{L}$. The milk FA thresholds for $\mathrm{C} 14: 0$ and $\mathrm{C} 15: 0$ were $\leq 6.8$ and $\leq 0.53$ $\mathrm{g} / 100 \mathrm{~g}$ of FA, respectively (Table 3). Craninx et al. (2008) reported that milk C15:0 represented a smaller proportion in the milk after calving and it increased as the lactation advanced until reaching a plateau at 10 wk of lactation. The increases in proportion $(\mathrm{g} / 100 \mathrm{~g}$ of FA) of this milk FA as DIM progressed is likely partially related to increased feed intake. Intake increases during the first weeks of lactation, and because the bacterial growth, particularly amylolytic bacteria, is expected to increase during that period (Craninx et al., 2008), de novo synthesis from propionyl-CoA by rumen bacteria or in the mammary gland might contribute to a greater proportion of $\mathrm{C} 15: 0$ in the milk (Vlaeminck et al., 2006).

Although the milk FA C18:1 was not selected due to having an AUC lower than $0.80(\mathrm{AUC}=0.77$, data not shown), its relationship with body fat mobilization as well as plasma NEFA concentration is known (Jorjong et al., 2015; Mann et al., 2016). It is important to highlight that in our data set, the milk FA cis-9 C18:1 was not separated on the GLC; thus, we were not able to compare thresholds across studies in the literature. The milk C18:1 in this present study is the sum of all $\mathrm{C} 18: 1$, though the major part of the total $\mathrm{C} 18: 1$ is cis-9 C18:1. The milk C18:1 in our study presented an AUC of 0.77 , which is a reasonable value. Considering the strong relationship between milk C18:1 and plasma NEFA concentration (Jorjong et al., 2015; Mann et al., 2016), a possible explanation for that value of AUC is the effect of dietary FA as previously described in the experiment 3 (R. Grummer, emeritus professor, University of Wisconsin, Madison, unpublished data). The use of 3 different studies with multiple diets may have resulted in more variation in the relationship between milk C18:1 and plasma NEFA concentration. In addition, reductions in milk fat output due to decreases in de novo milk FA synthesis may increase the proportion of milk C18:1. This fact might result in misinterpretation of the proportion of milk C18:1 because the increases were not due to body fat mobilization. The stearoylcoenzyme A desaturase (SCD) can also contribute to increase variation in milk C18:1. The SCD is the enzyme responsible for introducing a double bond at the $\Delta^{9}$ location of stearoyl-CoA, and oleic acid (C18:1) is the main product of this reaction. However, the SCD can be highly regulated in the mammary gland by the dietary ingredients, specifically FA sources. Jacobs et al. (2011) reported that mammary SCD1 mRNA expression in dairy cows was significantly downregulated by feeding unprotected soybean oil compared with rapeseed oil or linseed oil. Thus, it is important to highlight that depending on source of dietary FA supplied in dairy cow rations, the use of C18:1 to assess plasma NEFA concentration should be carefully evaluated.

Some limitations might exist regarding the amount of $\mathrm{C} 18: 1$ that can be incorporated in milk by cows during the transition period. This fact might increase the variation between plasma NEFA concentration and milk C18:1, especially when the milk FA is used as a ratio, such as C18:1 to C15:0 or other. We could not find studies in the literature to support the statement 
that this limitation exists or even reporting a threshold where milk C18:1 stop to increase and body fat mobilization still increasing. To elucidate this fact, we fitted milk C18:1 (g/100 g of FA) as exponential function of plasma NEFA concentration (Figure 1). An asymptote of $34.1 \mathrm{~g} / 100$ of FA was found in the present study, which means that milk C18:1 increases up to $34.1 \mathrm{~g} / 100$ $\mathrm{g}$ of FA and does not change above this value, whereas plasma NEFA concentration still increases.

The thresholds for the milk FA ratios $\mathrm{C} 18: 1$ to eSMCFA, C18:1 to C14:0, C18:1 to C15:0, and C17:0 to $\mathrm{C} 15: 0$ were $\geq 2.6, \geq 4.7, \geq 62$, and $\geq 0.95 \mathrm{~g} / \mathrm{g}$ of $\mathrm{FA}$, respectively. The milk FA ratio C18:1 to eSMCFA, C18:1 to C14:0, and C18:1 to C15:0 presented greater sensitivity (all presented 80.9\%), but not total accuracy (71, 70, and $79 \%$, respectively) in comparison with the milk FA ratio $\mathrm{C} 17: 0$ to $\mathrm{C} 15: 0$ (sensitivity of $72 \%$, but total accuracy of $84.3 \%$; Table 3). Although the milk FA C17:0 to C15:0 presented greater total accuracy, the ability to identify animals with $\mathrm{NEFA}_{\text {high }}$ was modest.

It is important to highlight that the milk FA C18:1 to C14:0 is composed of 2 milk FA with large proportions. This fact increases the chances of practical application due to the possibility of accurate predictions through mid-infrared (MIR) analyses (Soyeurt et al., 2006, 2011).

Nevertheless, these 2 milk FA might be drastically altered by changes in dietary FA profile. de Souza et al. $(2016,2017)$ reported reduction of de novo milk FA proportions (C6:0, C8:0, C10:0, C12:0, and C14:0) and C18:1 when palmitic acid (C16:0) was fed to lactating dairy cows. These studies suggest that predicting plasma NEFA from milk C18:1 and C14:0 is less reliable when cows are fed enriched FA supplements. Due to this potential shortcoming, we also tested the milk FA ratio C17:0 to C15:0 because this ratio is not generally disturbed by changes in dietary milk FA composition.

Another important application regarding the use of milk FA to predict plasma NEFA concentration is its applicability in research trials. When gross feed efficiency (milk/DMI) is calculated and there is no indicator of body fat mobilization, the measurement of feed efficiency might be inflated (Vallimont et al., 2011). Thus, the use of milk FA to assess body fat mobilization could be an important parameter to be added when inferences of gross feed efficiency are made in research trials.

Recently, Mann et al. (2016) addressed the possibility of using milk FA to infer information about plasma NEFA concentration. Those authors screened 22 individual milk FA and 2 milk FA ratios. From these 22 FA, only 3 individual milk FA (C15:0, cis-9 C16:1, and cis-9 C18:1) and 2 milk FA ratios (cis-9 C18:1 to C15:0, and cis-9 $\mathrm{C} 16: 1$ to $\mathrm{C} 15: 0)$ reached AUC greater than

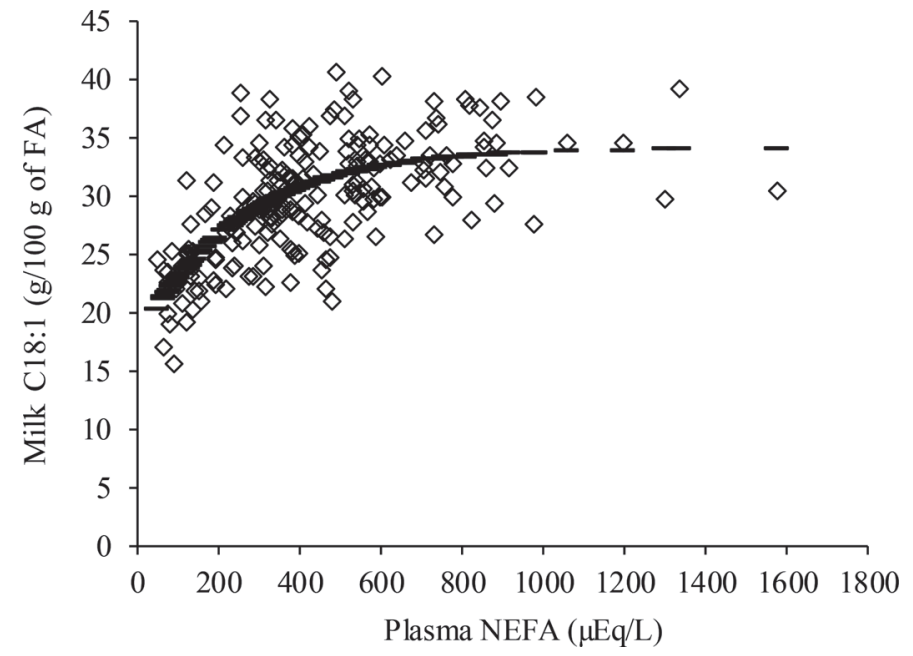

Figure 1. Relationship between plasma nonesterified fatty acid (NEFA) concentration and milk C18:1. Data are from all 3 studies (French et al., 2012; Lobos Sandoval, 2009; R. Grummer, emeritus professor, University of Wisconsin, Madison, personal communication; $\mathrm{n}=204)$. Nonlinear model was adjusted: milk C18:1 [g/100 of fatty acids $(\mathrm{FA})=34.1-16.9 \times \exp ^{(-0.004 \times \mathrm{NEFA})}\left(\mathrm{R}^{2}=0.42\right.$ and $\left.\left.P<0.001\right)\right]$, where $34.1 \mathrm{~g} / 100 \mathrm{~g}$ of FA is the estimated asymptote in the model. The $95 \%$ lower and upper confidence intervals for the asymptote were 32.4 and $35.8 \mathrm{~g} / 100 \mathrm{~g}$ of FA, respectively. Observed data $(\diamond)$, trend line $(-)$.

0.70 (considered as the selection criteria). Mann et al. (2016) used a plasma NEFA concentration of 1,000 $\mu \mathrm{Eq} / \mathrm{L}$ as the cutoff to classify a cow as having high or low NEFA concentration.

Differently from the study conducted by Mann et al. (2016), we were able to select SMCFA (Table 3), but not to select cis-9 C16:1. Milk C15:0 was selected in both Mann et al. (2016) and our study. The threshold for milk C15:0 found by Mann et al. (2016) was $\leq 0.65 \mathrm{~g} / 100$ of FA to detect cows with plasma NEFA higher than 1,000 $\mu \mathrm{Eq} / \mathrm{L}$. We found the milk C15:0 threshold of $\leq 0.53 \mathrm{~g} / 100$ of FA detected animals with plasma NEFA concentration greater than $600 \mu \mathrm{Eq} / \mathrm{L}$. In Jorjong et al. (2014), the threshold defined for milk cis-9 C18:1 was $\geq 24 \mathrm{~g} / 100 \mathrm{~g}$ of FA to detect cows with plasma NEFA greater than $600 \mu \mathrm{Eq} / \mathrm{L}$, whereas Mann et al. (2016) found a threshold of $\geq 26 \mathrm{~g} / 100 \mathrm{~g}$ of FA to detect cows with plasma NEFA greater than 1,000 $\mu \mathrm{Eq} / \mathrm{L}$. In our study the total milk C18:1 presented a threshold of $\geq 30 \mathrm{~g} / 100 \mathrm{~g}$ of FA (data not shown due to AUC $\leq 0.80)$.

The difference found across those studies can be attributed to many factors such as the difference in the cutoff to determine high/low plasma NEFA, milk FA sampling time (once vs. multiples), diets, number of animals, and so on. In this regard, the use of univariate logistic regression to define thresholds of determined milk FA to optimize sensitivity and specificity will re- 
sult in different values because they will differ from one group of animals to another.

Linear regression models that predicted plasma NEFA concentration using milk FA do not classify animals as $\mathrm{NEFA}_{\text {high }}$ or $\mathrm{NEFA}_{\text {low }}$ based in some threshold, but predict plasma NEFA concentration for a respective milk FA predictor. These predictions allow the users to set their own plasma NEFA cutoff to classify animals as having elevated plasma NEFA concentration.

\section{Linear Regression Models-Individual Cow (Internal Data Set)}

From the first milk FA screen using univariate logistic regression, 6 linear regression models were developed (Table 4). The forward stepwise selection of individual milk FA resulted in model 1, which presented the lowest RMSE and AIC $(169 \mu \mathrm{Eq} / \mathrm{L}$ and 2,473$)$. Another model also using individual milk FA was developed (model 2). Model 2 was developed from model 1 but had the milk C9:0 and C13:0 excluded from the model as previously explained.

The RMSE and AIC of model 2 increased after excluding the milk FA C9:0 and C13:0 (194 $\mu \mathrm{Eq} / \mathrm{L}$ and 2,672). Although these milk FA might improve the models, their proportions in the milk are very small and most published papers did not report them. Greater RMSE $(220$ and $205 \mu \mathrm{Eq} / \mathrm{L})$ and AIC $(2,742$ and 2,723) were found for the milk FA ratios C18:1 to eSMCFA and C18:1 to C14:0 (models 3 and 4, respectively) in comparison to the other ratios. The milk FA used in the 2 last ratios (C18:1, C14:0, and eSMCFA) can be highly influenced by dietary FA (Kalscheur et al., 1997). The variation associated with milk C18:1 might be explained through the multiple origins of C18:1 including C18:0 desaturation in the mammary gland, adipose tissue, and diet (Loften et al., 2014). The relationship between plasma NEFA concentration and those milk FA might be compromised if animals are being fed high-fat diets, but in our study even with 2 groups of cows from experiment 3 receiving greater amounts of dietary FA, the correlation was significant (Figure 2). Models 5 and 6 also presented good correlation with plasma NEFA concentration (Figure 2) in comparison with other models using milk FA ratios (model 3: $\mathrm{R}^{2}=0.21$, model 4: $\mathrm{R}^{2}=0.40$, model 5: $\mathrm{R}^{2}$ $=0.55$, and model $6: \mathrm{R}^{2}=0.53$ ).

Milk $\mathrm{C} 18: 1$ and C17:0 are correlated with plasma NEFA concentrations. Both are present in the adipose tissue and therefore in the large amount of NEFA released during fat mobilization that can be transferred to milk. According to Rukkwamsuk et al. (1999), about $44 \%$ of the total FA in the adipose tissue is C18:1, and $16 \%$ is C18:0. Approximately $52 \%$ of C18:0 uptake in the mammary gland is desaturated into cis-9 C18:1 (Enjalbert et al., 1998). Thus, there is a large contribution of $\mathrm{C} 18: 1$ from the adipose to the total milk C18:1. A greater proportion of milk C18:1 was identified as a valuable early warning biomarker for subclinical ketosis (Jorjong et al., 2014, 2015), which supports the high correlation between milk FA ratios using $\mathrm{C} 18: 1$ and plasma NEFA concentrations (Figure 2).

Linear odd-chain FA, C15:0 and C17:0, are mainly produced by the bacterial population in the rumen (Vlaeminck et al., 2006). They can also be synthetized from propionate in the adipose tissue, and the mamma-

Table 4. Models to predict plasma nonesterified fatty acid (NEFA) concentration from individual milk fatty acids (g/100 g of total fatty acids; $\mathrm{n}=204)$ and ratios of milk fatty acids $(\mathrm{g} / \mathrm{g} ; \mathrm{n}=204)^{1}$

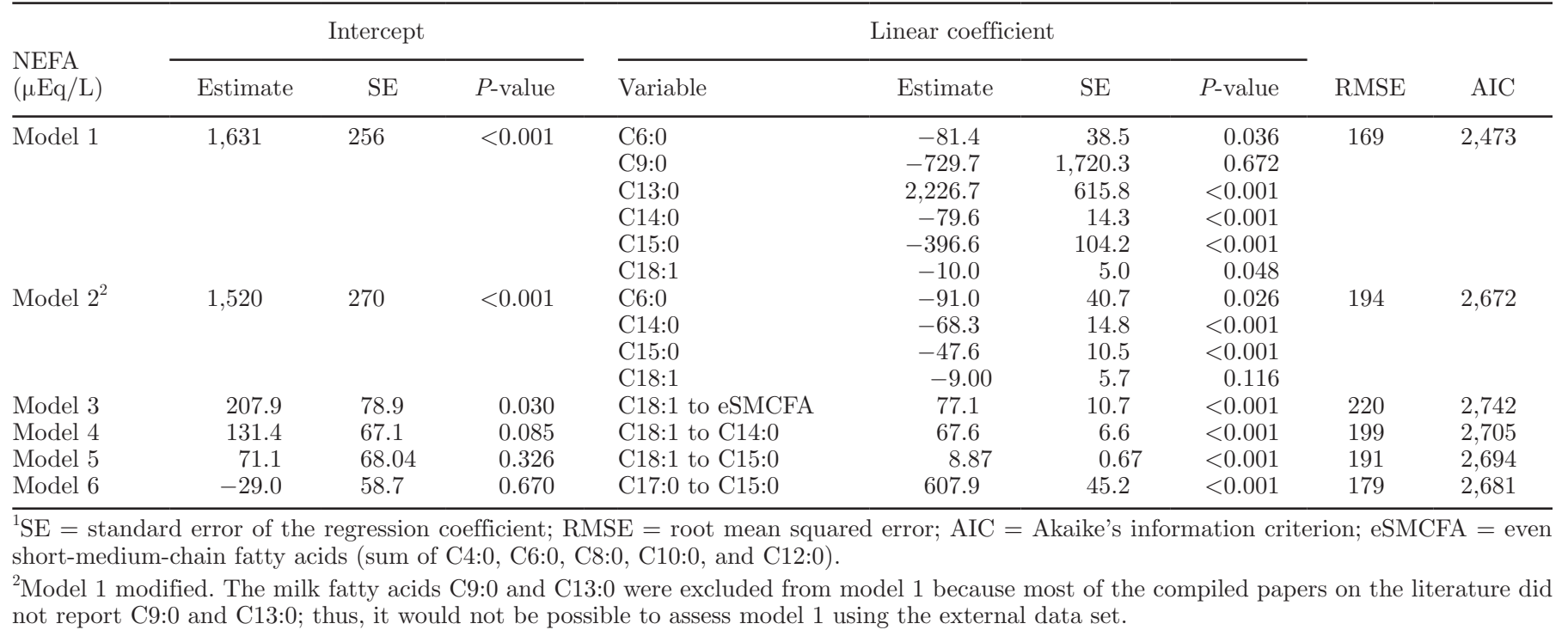



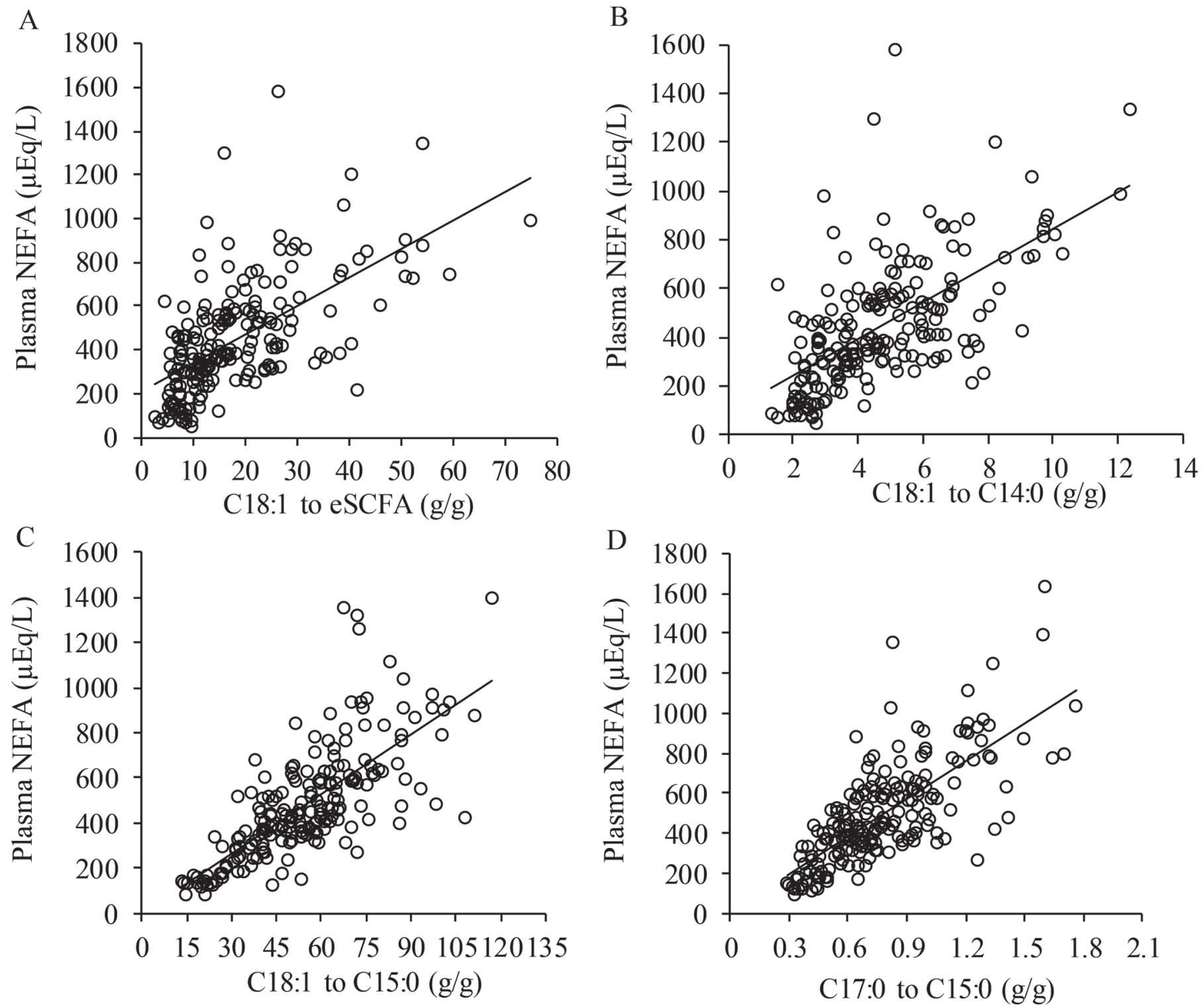

Figure 2. Model development (data set of individual cows from University of Wisconsin and US Dairy Forage Research Center). Linear regression between plasma nonesterified fatty acid (NEFA) concentration $(\mu \mathrm{Eq} / \mathrm{L})$ and milk fatty acid ratios [panel A: C18:1 to even shortmedium-chain fatty acids (eSMCFA); panel B: C18:1 to C14:0; panel C: C18:1 to C15:0; and panel D: C17:0 to C15:0; $\mathrm{n}=204$ observations from 105 cows]. For panels $\mathrm{A}, \mathrm{B}, \mathrm{C}$, and $\mathrm{D}$, the regression equation and $\mathrm{R}^{2}$ were $\hat{\mathrm{y}}=207.9+77.1 \mathrm{x}$, with $\mathrm{R}^{2}$ of 0.21 and $P<0.001 ; \hat{\mathrm{y}}=67.6 \mathrm{x}$, with $\mathrm{R}^{2}$ of 0.40 and $P<0.001 ; \hat{\mathrm{y}}=8.87 \mathrm{x}$, with $\mathrm{R}^{2}$ of 0.55 and $P<0.001$; and $\hat{\mathrm{y}}=607.9 \mathrm{x}$, with $\mathrm{R}^{2}$ of 0.53 and $P<0.001$. Observed data $(O)$, trend line $(-)$.

ry gland (Vlaeminck et al., 2006). The contribution of de novo synthesis by the mammary gland as a proportion of the individual FA total seemed to be greater for C15:0 than for C17:0 when propionic acid was infused into the rumen (Rigout et al., 2003). The synthesis of C17:0 in the adipose tissue is considered preferential in comparison with synthesis of chain lengths of 14 and 15 carbon atoms (Craninx et al., 2008). Thus, the ratio between $\mathrm{C} 17: 0$ and $\mathrm{C} 15: 0$ in the adipose tissue is approximately $3: 1$ in cattle (Raes et al., 2004), but 1:2 in the milk, suggesting that increases in C17:0 to C15:0 ratio could be related to increased fat mobilization.

\section{Model Validation-External Data Set}

Models developed using the individual animal data set (experiments from University of Wisconsin and USDFRC) were compared with models developed from the literature data set (treatment means) to evaluate the goodness of fit between predicted plasma NEFA. 
Table 5. Parameters evaluation of plasma nonesterified fatty acid (NEFA) predictions from different models using milk fatty acids ${ }^{1}$

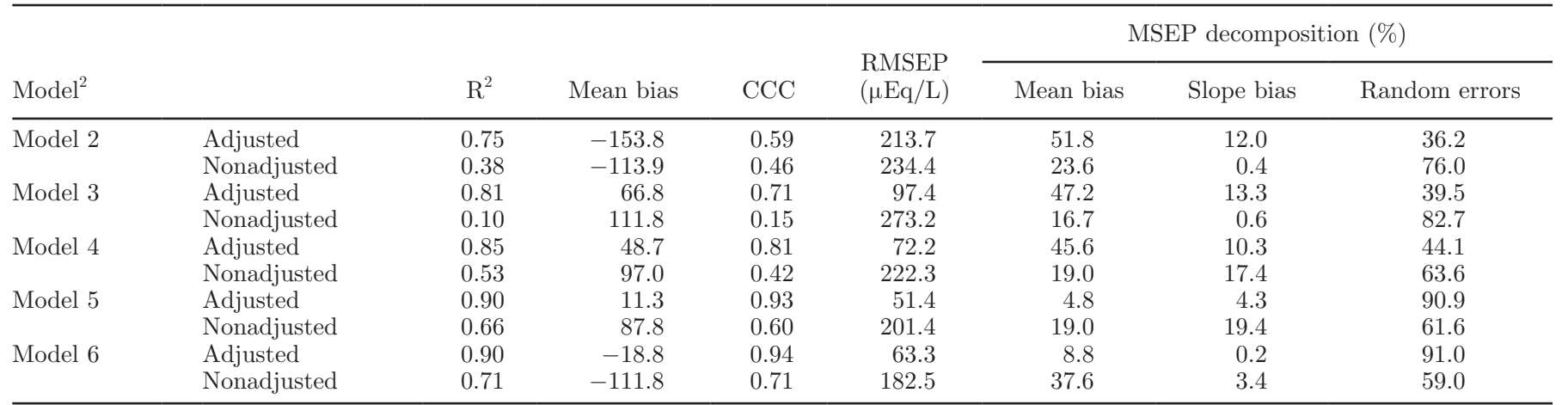

${ }^{1} \mathrm{CCC}=$ concordance correlation coefficient; RMSEP $=$ root mean squared errors of prediction; MSEP $=$ mean squared errors of prediction. Adjusted = data set from the literature adjusted for a random effect of study; nonadjusted = data set from the literature nonadjusted for random effect of study (raw data).

${ }^{2}$ Model $2=$ individual milk fatty acids proportions C6:0, C14:0, C15:0, and C18:1; model $3=\mathrm{C} 18: 1$ to even short-medium-chain fatty acids (eSMCFA); model $4=\mathrm{C} 18: 1$ to C14:0; model $5=\mathrm{C} 18: 1$ to C15:0; and model $6=\mathrm{C} 17: 0$ to C15:0.

Our main objective in this model evaluation was to test if the relationship found in our internal data set was a local correlation or if it can be generalized across a wider population.

The model prediction using individual milk FA proportions (model 2) presented a coefficient of determination value of 0.75 with observed data, but also a large amount of prediction error due to MB. The MB and RMSEP were -153.8 and $213.7 \mu \mathrm{Eq} / \mathrm{L}$, respectively, and approximately $52 \%$ of the RMSEP came from MB in model 2 (Table 5). This high MB and RMSEP seems to be related to variation on eSMCFA, because the model using the milk FA ratio $\mathrm{C} 18: 1$ to eSMCFA (model 3) presented greater MB $(66.8 \mu \mathrm{Eq} / \mathrm{L})$ and RMSEP $(97.4 \mu \mathrm{Eq} / \mathrm{L})$ in comparison to models 4,5 , and 6 even though model 3 presented a good correlation between predicted and observed $\left(\mathrm{R}^{2}=0.81\right)$.

Models 4,5 , and 6 presented greater precision $\left(\mathrm{R}^{2}\right.$ $=0.85,0.90$, and 0.90, respectively), and lower $\mathrm{MB}$ (48.7, 11.3, and $-18.8 \mu \mathrm{Eq} / \mathrm{L}$ ) and RMSEP (72.2, 51.4 , and $63.3 \mu \mathrm{Eq} / \mathrm{L}$ ) in comparison with models 2 and 3. The model using the milk FA ratio $\mathrm{C} 18: 1$ to C14:0 as a predictor variable fit the external data set slightly more poorly than model 5 and 6 . This result was expected because a greater variation of milk C18:1 and C14:0 would be expected because they can come from multiple origins (Loften et al., 2014) as previously discussed. However, it is important to recognize that these FA represent large proportions in the milk, and their determination using GLC might present lower coefficient of variation in comparison with smaller milk FA such as the short-chain fatty acids (Bannon et al., 1985). The 3 experiments used to develop the models had C14:0 values of 9.6, 7.1, and $6.3 \mathrm{~g} / 100$ of FA, and C18:1 values of $23.0,30.4$, and $34.4 \mathrm{~g} / 100 \mathrm{~g}$ of $\mathrm{FA}$, respectively. The sum of these 2 milk FA represents approximately 32,37 , and $40 \%$ of the total FA in the milk.

Equations created from the literature data set for models 5 and 6 were NEFA $(\mu \mathrm{Eq} / \mathrm{L})=9.37( \pm 2.18) \times$ $\mathrm{C} 18: 1$ to $\mathrm{C} 15: 0\left(\mathrm{R}^{2}=0.88\right)$ and NEFA $(\mu \mathrm{Eq} / \mathrm{L})=593.9$ $( \pm 103.4) \times \mathrm{C} 17: 0$ to $\mathrm{C} 15: 0\left(\mathrm{R}^{2}=0.90\right)$ respectively. The intercepts of these equations were not significantly different from $0(P=0.48$, and $P=0.16$, respectively $)$. The slopes were close to the previous model developed using individual animals (Model $5=8.87 \times \mathrm{C} 18: 1$ to C15:0, and model $6=607.9 \times \mathrm{C} 17: 0$ to C15:0, Table $4)$, which can explain the good fit of models at the individual animal level (internal data set) with treatment mean level (external data set). The equations developed using treatment means might be useful for predicting the mean of a group of cows in specific cohorts (i.e., pens with cows in transition period) or bulk tank milk samples. The recent study conducted by Woolpert et al. (2016) showed that the analyses of FA from bulk tank milk samples might exhibit the farm profile in terms of management factors such as feeding frequency, dietary ether extract concentration, BCS, and stocking density.

The possibility of using MIR techniques to predict milk FA has been widely discussed (Soyeurt et al., 2006; Ferrand-Calmels et al., 2014; Woolpert et al., 2016) during the last $10 \mathrm{yr}$ and may become as common as fat, protein, and lactose milk analyses in the future. Thus, precise and accurate predictions of milk FA such as C18:1, C14:0, and eSMCFA from MIR could be useful in assessing adipose tissue mobilization in lactating dairy cows.

Fatty acids present in large proportions in the milk fat, such as C18:1, C18:0, C16:0, C14:0, and eSMCFA, have been reported to be precisely predicted by MIR (Soyeurt et al., 2006, 2011; Woolpert et al., 2016). The reported MIR predictions for C17:0 and C15:0 are not 
as good (cross-validation $\mathrm{R}^{2}=0.47$ and 0.53 , respectively) as for milk FA presented in large proportions such as cis-9 C18:1 and C16:0 (cross-validation $\mathrm{R}^{2}=$ 0.95 and 0.91, respectively; Soyeurt et al., 2006, 2011). Although a good relationship was found in the present study regarding the milk FA ratio using C15:0 and C17:0, the poor predictions by MIR reported in the literature might limit the use of those milk FA as an indicator of NEB in the future.

\section{CONCLUSIONS}

The results of this study indicated that milk FA determined by GLC are related to plasma NEFA concentration, and its selection by univariate logistic regression can be used to identify animals with plasma NEFA above $600 \mu \mathrm{Eq} / \mathrm{L}$. Plasma NEFA concentration can also be predicted by linear regression models using milk FA ratios. The linear regressions allowed the user to define their plasma NEFA cutoff to classify cows as having high or low NEFA. The developed linear regressions using the milk FA ratios $\mathrm{C} 18: 1$ to $\mathrm{C} 15: 0$ and $\mathrm{C} 17: 0$ to C15:0 were consistently related to plasma NEFA concentration and had a better fit with the external data set in comparison with the use of individual milk FA proportions, milk FA ratio C18:1 to eSMCFA, and C18:1 to C14:0. This fact suggests that those models had not just a local relationship (within internal data set), but a good fit in an independent data set (external data set from the literature).

\section{ACKNOWLEDGMENTS}

Thanks are extended to Michel A. Wattiaux (University of Wisconsin, Madison) for permission to use data from the second study (Lobos Sandoval, 2009), and to Ric Grummer (University of Wisconsin, Madison) and Silvia Onetti (Vita Plus Corporation, Madison, WI) for permission to use data from the third study. Thanks are also extended to Sandy Bertics (University of Wisconsin, Madison) for analyzing the milk fatty acids, and Kristina Weld (University of Wisconsin, Madison) for the technical advice. The authors thank the Brazilian National Council for Scientific and Technological Development (CNPq, Brasilia-DF, Brazil) for providing part of the financial support for J. R. R. Dórea.

\section{REFERENCES}

Bannon, C. D., J. D. Craske, and A. E. Hilliker. 1985. Analysis of fatty acid methyl esters with high accuracy and reliability. Fats with fatty acids containing four or more carbon atoms. J. Am. Oil Chem. Soc. 62:1501-1507. https://doi.org/10.1007.BF02541903.

Baumgard, L. H., B. A. Corl, D. A. Dwyer, A. Saebo, and D. E. Bauman. 2000. Identification of the conjugated linoleic acid isomer that inhibits milk fat synthesis. Am. J. Physiol. Regul. Integr. Comp. Physiol. 278:R179-R184.

Benchaar, C., T. A. McAllister, H. Petit, and P. Y. Chouinard. 2014. Whole flax seed and flax oil supplementation of dairy cows fed high-forage or high-concentrate diets: Effects on digestion, ruminal fermentation characteristics, protozoal populations and milk fatty acid profile. Anim. Feed Sci. Technol. 198:117-129. https://doi. org/10.1016/j.anifeedsci.2014.10.003.

Bernal-Santos, G., J. W. Perfield II, D. M. Barbano, D. E. Bauman, and T. R. Overton. 2003. Production responses of dairy cows to dietary supplementation with conjugated linoleic acid (CLA) during the transition period and early lactation. J. Dairy Sci. 86:32183228. https://doi.org/10.3168/jds.S0022-0302(03)73925-3.

Bibby, J., and H. Toutenburg. 1977. Prediction and Improved Estimation in Linear Models. John Wiley and Sons, Berlin, Germany.

Castañeda-Gutiérrez, E., T. R. Overton, W. R. Butler, and D. E. Bauman. 2005. Dietary supplements of two doses of calcium salts of conjugated linoleic acid during the transition period and early lactation. J. Dairy Sci. 88:1078-1089. https://doi.org/10.3168/jds. S0022-0302(05)72775-2.

Chouinard, P. Y., L. Corneau, A. Sæbø, and D. E. Bauman. 1999 Milk yield and composition during abomasal infusion of conjugated linoleic acids in dairy cows. J. Dairy Sci. 82:2737-2745. https:// doi.org/10.3168/jds.S0022-0302(99)75530-X .

Collard, B. L., J. C. M. Dekkers, D. Petitclerc, and L. R. Schaeffer. 2000. Relationships between energy balance and health traits of dairy cattle in early lactation. J. Dairy Sci. 83:2683-2690. https:// doi.org/10.3168/jds.S0022-0302(00)75162-9.

Craninx, M., A. Steen, H. Van Laar, T. Van Nespen, J. Martin-Tereso, B. De Baets, and V. Fievez. 2008. Effect of lactation stage on the odd- and branched-chain milk fatty acids of dairy cattle under grazing and indoor conditions. J. Dairy Sci. 91:2662-2677. https:// doi.org/10.3168/jds.2007-0656.

Dann, H. M., D. E. Morin, M. R. Murphy, G. A. Bollero, and J. K. Drackley. 2005. Prepartum intake, postpartum induction of ketosis, and periparturient disorders affect the metabolic status of dairy cows. J. Dairy Sci. 88:3249-3264. https://doi.org/10.3168/ jds.S0022-0302(05)73008-3.

de Souza, J., L. Garver, C. L. Preseault, and A. L. Lock. 2017. Short communication: Effects of prill size of a palmitic acid-enriched fat supplement on the yield of milk and milk components, and nutrient digestibility of dairy cows. J. Dairy Sci. 100:379-384. https:// doi.org/10.3168/jds.2016-11610.

de Souza, J., C. L. Preseault, and A. L. Lock. 2016. Short communication: Lactational responses to palmitic acid supplementation when replacing soyhulls or dry ground corn. J. Dairy Sci. 99:1945-1950. https://doi.org/10.3168/jds.2015-10367.

Dohoo, I., W. Martin, and H. Stryhn. 2003. Screening and diagnostic tests. Pages $85-120$ in Veterinary Epidemiologic Research, 1st ed. S. M. McPike, ed. University of Prince Edward Island, AVC Inc., Charlottetown, PEI, Canada.

Enjalbert, F., M.-C. Nicot, C. Bayourthe, and R. Moncoulon. 1998 Duodenal infusions of palmitic, stearic or oleic acids differently affect mammary gland metabolism of fatty acids in lactating dairy cows. J. Nutr. 128:1525-1532.

Ferlay, A., B. Martin, Ph. Pradel, J. B. Coulon, and Y. Chilliard 2006. Influence of grass-based diets on milk fatty acid composition and milk lipolytic system in Tarentaise and Montbéliarde cow breeds. J. Dairy Sci. 89:4026-4041. https://doi.org/10.3168/jds. S0022-0302(06)72446-8.

Ferrand-Calmels, M., I. Palhière, M. Brochard, O. Leray, J. M. Astruc M. R. Aurel, S. Barbey, F. Bouvier, P. Brunschwig, H. Caillat, M. Douguet, F. Facuon-Lahalle, M. Gele, G. Thomas, J. M. Thrommenschlager, and H. Larroque. 2014. Prediction of fatty acid profiles in cow, ewe, and goat milk by mid-infrared spectrometry. J. Dairy Sci. 97:17-35. https://doi.org/10.3168/jds.2013-6648.

French, E. A., S. J. Bertics, and L. E. Armentano. 2012. Rumen and milk odd and branched-chain fatty acid proportions were minimally influenced by ruminal volatile fatty acid infusions. J. Dairy Sci. 95:2015-2026. https://doi.org/10.3168/jds.2011-4827. 
Gonthier, C., A. F. Mustafa, D. R. Ouellet, P. Y. Chouinard, R. Berthiaume, and H. V. Petit. 2005. Feeding micronized and extruded flaxseed to dairy cows: Effects on blood parameters and milk fatty acid composition. J. Dairy Sci. 88:748-756. https://doi. org/10.3168/jds.S0022-0302(05)72738-7.

Griinari, J. M., M. A. Mc. Guire, D. A. Dwyer, D. E. Bauman, and D. L. Palmquist. 1997. Role of insulin in the regulation of milk fat synthesis in dairy cows. J. Dairy Sci. 80:1076-1084. https://doi. org/10.3168/jds.S0022-0302(97)76032-6.

Grummer, R. R. 1993. Etiology of lipid-related metabolic disorders in periparturient dairy cows. J. Dairy Sci. 76:3882-3896.

Halmemies-Beauchet-Filleau, A., T. Kokkonen, A.-M. Lampi, V Toivonen, K. J. Shingfield, and A. Vanhatalo. 2011. Effect of plant oils and camelina expeller on milk fatty acid composition in lactating cows fed diets based on red clover silage. J. Dairy Sci. 94:44134430. https://doi.org/10.3168/jds.2010-3885.

Hara, A., and N. S. Radin. 1978. Lipid extraction of tissues with a low-toxicity solvent. Anal. Biochem. 90:420-426.

Jacobs, A. A. A., J. van Baal, M. A. Smits, H. Z. H. Taweel, W. H. Hendriks, A. M. van Vuuren, and J. Dijkstra. 2011. Effects of feeding rapeseed oil, soybean oil, or linseed oil on stearoyl-CoA desaturase expression in the mammary gland of dairy cows. J. Dairy Sci. 94:874-887. https://doi.org/10.3168/jds.2010-3511.

Jenkins, T. C. 1999. Lactation performance and fatty acid composition of milk from Holstein cows fed 0 to $5 \%$ oleamide. J. Dairy Sci. 82:1525-1531. https://doi.org/10.3168/jds.S0022-0302(99)75379-

Jorjong, S., A. T. M. van Knegsel, J. Verwaeren, M. V. Lahoz, R. M. Bruckmaier, B. De Baets, B. Kemp, and V. Fievez. 2014. Milk fatty acids as possible biomarkers to early diagnose elevated concentrations of blood plasma non-esterified fatty acids in dairy cows. J. Dairy Sci. 97:7054-7064. https://doi.org/10.3168/jds.2014-8039.

Jorjong, S., A. T. M. van Knegsel, J. Verwaeren, R. M. Bruckmaier, B. De Baets, B. Kemp, and V. Fievez. 2015. Milk fatty acids as possible biomarkers to diagnose hyperketonemia in early lactation. J. Dairy Sci. 98:5211-5221. https://doi.org/10.3168/jds.2014-8728.

Kalscheur, K. F., B. B. Teter, L. S. Piperova, and R. A. Erdman. 1997. Effect of fat source on duodenal flow of trans-C18:1 fatty acids and milk fat production in dairy cows. J. Dairy Sci. 80:2115-2126. https://doi.org/10.3168/jds.S0022-0302(97)76157-5.

Kay, J. K., T. R. Mackle, D. E. Bauman, N. A. Thomson, and L. H. Baumgard. 2007. Effects of a supplement containing trans-10, cis12 conjugated linoleic acid on bioenergetic and milk production parameters in grazing dairy cows offered ad libitum or restricted pasture. J. Dairy Sci. 90:721-730. https://doi.org/10.3168/jds. S0022-0302(07)71556-4

Lerch, S., J. A. A. Pires, C. Delavaud, K. J. Shingfield, D. Pomiès, B. Martin, P. Y. Chilliard, and A. Ferlay. 2015. Rapeseed or linseed in dairy cow diets over 2 consecutive lactations: Effects on adipose fatty acid profile and carry-over effects on milk fat composition in subsequent early lactation. J. Dairy Sci. 98:1005-1018. https:// doi.org/10.3168/jds.2014-8578.

Lin, L. I. 1989. A concordance correlation coefficient to evaluate reproducibility. Biometrics 45:255-268.

Lobos Sandoval, N. E. 2009. A study of urea nitrogen in colostrum, milk and blood, and plasma non-esterified fatty acids in relation to energy balance in peri-parturient primiparous and multiparous Holstein cows. MS Thesis (advisor: M. A. Wattiaux), Department of Dairy Science, University of Wisconsin, Madison.

Loften, J. R., J. G. Linn, J. K. Drackley, T. C. Jenkins, C. G. Soderholm, and A. F. Kertz. 2014. Invited review: Palmitic and steric acid metabolism in lactating dairy cows. J. Dairy Sci. 97:46614674. https://doi.org/10.3168/jds.2014-7919.

Loor, J. J., A. Ferlay, A. Ollier, M. Doreau, and Y. Chilliard. 2005a. Relationship among trans and conjugated fatty acids and bovine milk fat yield due to dietary concentrate and linseed oil. J. Dairy Sci. 88:726-740. https://doi.org/10.3168/jds.S0022-0302(05)72736-3.

Loor, J. J., A. Ferlay, A. Ollier, K. Ueda, M. Doreou, and Y. Chilliard. 2005b. High concentrate diet and polyunsaturated oils alter trans and conjugated isomer in bovine rumen, blood and milk.
J. Dairy Sci. 88:3986-3999. https://doi.org/10.3168/jds.S00220302(05)73085-X

Mandebvu, P., C. S. Ballard, C. J. Sniffen, M. P. Carter, H. M. Wolford, T. Sato, Y. Yabuuchi, E. B. Block, and D. L. Palmquist. 2003. Effect of feeding calcium salts of long-chain fatty acids, from palm fatty acid distillate or soybean oil, to high producing dairy cows on milk yield and composition, and on selected blood and reproductive parameters. Anim. Feed Sci. Technol. 108:25-41. https://doi.org/10.1016/S0377-8401(03)00133-0.

Mann, S., D. V. Nydam, A. L. Lock, T. R. Overton, and J. A. A. McArt. 2016. Short communication: Association of milk fatty acids with early lactation hyperketonemia and elevated concentration of nonesterified fatty acids. J. Dairy Sci. 99:5851-5857. https://doi. org $/ 10.3168 /$ jds.2016-10920

Moore, C. E., H. C. Hafliger III, O. B. Mendivil, S. R. Sanders, D. E. Bauman, and L. H. Baumgard. 2004. Increasing amounts of conjugated linoleic acid (CLA) progressively reduces milk fat synthesis immediately postpartum. J. Dairy Sci. 87:1886-1895. https://doi. org/10.3168/jds.S0022-0302(04)73347-0.

Novak, M. 1965. Colorimetric ultramicro method for the determination of free fatty acids. J. Lipid Res. 6:431-433.

Odens, L. J., R. Burgos, M. Innocenti, M. J. VanBaale, and L. H. Baumgard. 2007. Effects of varying doses of supplemental conjugated linoleic acid on production and energetic variables during the transition period. J. Dairy Sci. 90:293-305. https://doi. org/10.3168/jds.S0022-0302(07)72630-9.

Ospina, P. A., D. V. Nydam, T. Stokol, and T. R. Overton. 2010. Associations of elevated nonesterified fatty acids and $\beta$-hydroxybutyrate concentrations with early lactation reproductive performance and milk production in transition dairy cattle in the northeastern United States. J. Dairy Sci. 93:1596-1603. https://doi.org/10.3168/ jds.2009-2852

Penner, G. B., and M. Oba. 2009. Increasing dietary sugar concentration may improve dry matter intake, ruminal fermentation, and productivity of dairy cows in the postpartum phase of the transition period. J. Dairy Sci. 92:3341-3353. https://doi.org/10.3168/ jds.2008-1977.

Petit, H. V. 2015. Milk production and composition, milk fatty acid profile, and blood composition of dairy cows fed different proportions of whole flaxseed in the first half of lactation. Anim. Feed Sci. Technol. 205:23-30. https://doi.org/10.1016/j. anifeedsci.2015.04.009.

Petit, H. V., and C. Côrtes. 2010. Milk production and composition, milk fatty acid profile, and blood composition of dairy cows fed whole or ground flaxseed in the first half of lactation. Anim. Feed Sci. Technol. 158:36-43. https://doi.org/10.1016/j. anifeedsci.2010.03.013.

Pineda, A., and F. C. Cardoso. 2015. Effects of rumen-protected choline with calcium salts of long chain fatty acids on milk yield and milk composition of middle and late lactation Holstein cows. Anim. Feed Sci. Technol. 175:47-58. https://doi.org/10.1016/j. livsci.2015.02.005.

Raes, K., S. De Smet, and D. Demeyer. 2004. Effect of dietary fatty acids on incorporation of long chain polyunsaturated fatty acids and conjugated linoleic acid in lamb, beef and pork meat: A review. Anim. Feed Sci. Technol. 113:199-221. https://doi.org/10.1016/j. anifeedsci.2003.09.001.

Resende, T. L., J. Kraft, K. J. Soder, A. B. D. Pereira, D. E. Woitschach, R. B. Reis, and A. F. Brito. 2015. Incremental amounts of ground flaxseed decrease milk yield but increase n-3 fatty acids and conjugated linoleic acids in dairy cows fed high-forage diets. J. Dairy Sci. 98:4785-4799. https://doi.org/10.3168/jds.2014-9115.

Rigout, S., C. Hurtaud, S. Lemosquet, A. Bach, and H. Rulquin. 2003. Lactational effect of propionic acid and duodenal glucose in cows. J. Dairy Sci. 86:243-253. https://doi.org/10.3168/jds.S00220302(03)73603-0.

Rukkwamsuk, T., T. Wensin, and M. J. H. Geelen. 1999. Effect of overfeeding during the dry period on the rate of esterification in adipose tissue of dairy cows during the periparturient period. J. Dairy Sci. 82:1164-1169. https://doi.org/10.3168/jds.S00220302(99)75339-7. 
Soyeurt, H., P. Dardenne, F. Dehareng, G. Lognay, D. Veselko, M. Marlier, C. Bertozzi, P. Mayeres, and N. Gengler. 2006. Estimating fatty acid content in cow milk using mid-infrared spectrometry. J. Dairy Sci. 89:3690-3695. https://doi.org/10.3168/jds.S00220302(06)72409-2.

Soyeurt, H., F. Dehareng, N. Gengler, S. McParland, E. Wall, D. P Berry, and M. Coffey. 2011. Mid-infrared prediction of bovine milk fatty acids across multiple breeds, production systems, and countries. J. Dairy Sci. 94:1657-1667. https://doi.org/10.3168/ jds.2010-3408.

St-Pierre, N. R. 2001. Integrating quantitative findings from multiple studies using mixed model methodology. J. Dairy Sci. 84:741-755. https://doi.org/10.3168/jds.S0022-0302(01)74530-4.

Tedeschi, L. O. 2006. Assessment of the adequacy of mathematical models. Agric. Syst. 89:225-247. https://doi.org/10.1016/j. agsy.2005.11.004

Theil, H. 1961. Economic forecasts and policy. Pages 6-48 in Contributions to Economic Analysis. R. Strotz, J. Tinbergen, P. Verdoorn, and H. J. Witteveen, ed. North-Holland Publishing Company, Amsterdam, the Netherlands.

Vallimont, J. E., C. D. Dechow, J. M. Daubert, M. W. Dekleva, J. W. Blum, C. M. Barlieb, W. Liu, G. A. Varga, A. J. Heinrichs, and C. R. Baumrucker. 2011. Heritability of gross feed efficiency and associations with yield, intake, residual intake, body weight, and body condition score in 11 commercial Pennsylvania tie stalls. J. Dairy Sci. 94:2108-2113. https://doi.org/10.3168/jds.2010-3888.

van Knegsel, A. T. M., H. van den Brand, J. Dijkstra, S. Tamminga, and B. Kemp. 2005. Effect of dietary energy source on energy balance, production, metabolic disorders and reproduction in lactating dairy cattle. Reprod. Nutr. Dev. 45:665-688. https://doi org/10.1051/rnd:2005059.

Vlaeminck, B., V. Fievez, A. R. J. Cabrita, A. J. M. Fonseca, and R. J. Dewurst. 2006. Factors affecting odd- and branched-chain fatty acids in milk: A review. Anim. Feed Sci. Technol. 131:389-417. https://doi.org/10.1016/j.anifeedsci.2006.06.017.

Woolpert, M. E., H. M. Dann, K. W. Cotanch, C. Melilli, L. E. Chase, R. J. Grant, and D. M. Barbano. 2016. Management, nutrition, and lactation performance are related to bulk tank milk de novo fatty acid concentration on northeastern US dairy farms. J. Dairy Sci. 99:8486-8497. https://doi.org/10.3168/jds.2016-10998.

Zachut, M., A. Arieli, H. Lehrer, L. Livshitz, S. Yakoby, and U. Moallem. 2010. Effects of increased supplementation of $n-3$ fatty acids to transition dairy cows on performance and fatty acid profile in plasma, adipose tissue, and milk fat. J. Dairy Sci. 93:5877-5889. https://doi.org/10.3168/jds.2010-3427. 